\title{
Reducing the costs to health systems of unsafe abortion: a comparison of four strategies
}

\author{
Heidi B Johnston, Maria F Gallo, Janie Benson
}

\begin{abstract}
Background and methodology Strategies to reduce health systems costs of providing abortion and post-abortion care while simultaneously improving quality of care are well documented but infrequently applied. We created 'Savings', a spreadsheet-based tool that allows policymakers and other stakeholders to estimate and compare the feasibility and sustainability of different strategies of providing abortion and post-abortion care. By applying cost data primarily from Uganda, we showed the per-case costs under four policy and service delivery scenarios.
\end{abstract}

Results The mean per-case cost of abortion care (in US dollars) was $\$ 45$ within the setting that placed heavy restrictions on elective abortion and used a conventional approach to service delivery; $\$ 25$ within the restrictive legal setting that used recommended interventions for treating complications; \$34 within the legal setting that allowed elective abortion and relied on a conventional approach to service delivery; and \$6 within the liberal legal setting that used recommended interventions.

Discussion and conclusions Using recommended technical interventions substantially reduced costs regardless of the legal setting. The greatest reduction in costs $(86 \%)$ occurred from using recommended interventions within a liberal legal setting rather than using conventional interventions within a restricted setting. These findings should support policy and practice efforts to reform abortion laws and to offer accessible, safe abortion services.

Keywords abortion, costs, economics, post-abortion care, reproductive health services

J Fam Plann Reprod Health Care 2007; 33(4): 250-257 (Accepted 3 August 2007)

\section{Introduction}

The United Nations' Millennium Development Goal calling for the reduction of maternal mortality by $75 \%$ between 1990 and $2015^{1}$ will not be met without addressing unsafe abortion. Unsafe abortion - defined as "a procedure for terminating unwanted pregnancy either by persons lacking the necessary skills or in an environment lacking the minimal medical standards, or both" 2 - causes an estimated $13 \%$ of maternal mortality globally and is a leading cause of maternal morbidity, such as infection, hemorrhage, cervical laceration, and uterine perforation. ${ }^{3}$ The unsafe abortion mortality ratio is highest in Africa at 100 per 100000 live births. The ratio is 40 per 100000 live births in Asia and 30 in Latin America and the Caribbean, whereas in developed countries it is only $3 .{ }^{4}$ In some developing countries, as much as 50\% of obstetricgynaecology budgets may be spent on treating abortion complications. ${ }^{5}$

Abortion care has four components: (1) elective induced abortion services; (2) emergency treatment of complications of spontaneous or unsafely performed induced abortion; (3) post-abortion contraceptive counselling and method provision to prevent repeat unwanted pregnancy; and (4) links between elective or treatment services and other reproductive health care. During the last decade, international agreements have affirmed governmental obligations to make abortion services safe and accessible to the extent allowed by law.4,6

The technical interventions needed to reduce costs to health systems and simultaneously improve the availability and quality of abortion-related care are well understood 3,7

ICDDR,B, Public Health Sciences Division, Dhaka, Bangladesh Heidi B Johnston, PhD, Social Scientist

Ipas, Research and Evaluation, Chapel Hill, NC, USA Maria F Gallo, PhD, Researcher

Janie Benson, DrPH, Vice-President, Research and Evaluation

Correspondence to: Dr Heidi Johnston, ICDDR,B, Public Health Sciences Division, Mohakhali, Dhaka 1212, Bangladesh. E-mail: hjohnston@icddrb.org

\section{Key message points}

- 'Savings' is a spreadsheet-based tool that enables stakeholders to estimate and compare health system costs of different strategies of abortion care.

- This application of the 'Savings' model shows that regardless of whether abortion law is restrictive or liberal, an approach based on recommended technical interventions for abortion-related care delivered at a decentralised level could reduce costs substantially compared to a conventional approach.

- However, the application suggests that the greatest savings coincide with a shift from a conventional approach within a restricted abortion law setting to a recommended approach within a liberal setting.

and include replacing dilation and curettage (D\&C) for uterine evacuation with vacuum aspiration (electric or manual vacuum aspiration depending on the health system level and resources available); using outpatient facilities rather than operating theatres; and using mid-level providers instead of specialists to provide care. ${ }^{8-19}$ Also, availability of abortion care at a decentralised level, in primary as well as secondary and tertiary health facilities, is important for reducing costs and ensuring accessibility of services to women. These interventions, despite the advantages in terms of cost and safety, often are not implemented or are used inconsistently.?

We developed 'Savings', a Microsoft Excel ${ }^{\mathrm{TM}}$ spreadsheet-based tool, to enable comparisons of the relative costs of implementing different strategies of abortion care in particular geopolitical settings. 'Savings' is similar to other tools and guidelines that have been developed for estimating costs of reproductive health interventions or services, including the Cost Analysis Tool (CAT) by EngenderHealth (New York, NY), the Cost and Revenue Analysis Tool (CORE) and the Cost-Estimate Strategy (CES) by Management Sciences for Health,20,21 SPECTRUM by The Policy II Project, ${ }^{22}$ and the Mother-Baby Package by the World Health Organization (WHO). ${ }^{23-25}$ However, none of these existing tools has addressed abortion care comprehensively. The limited research conducted on the costs of abortion care in the public sector generally has been directed toward estimating 
Table 1 Characteristics of four scenarios for abortion care service delivery

\begin{tabular}{|c|c|c|c|c|}
\hline \multirow[t]{2}{*}{ Characteristic } & \multicolumn{4}{|l|}{ Scenario } \\
\hline & $\begin{array}{l}\text { Restrictive law/ } \\
\text { conventional service }\end{array}$ & $\begin{array}{l}\text { Restrictive law/ } \\
\text { recommended service }\end{array}$ & $\begin{array}{l}\text { Liberal law/ } \\
\text { conventional service }\end{array}$ & $\begin{array}{l}\text { Liberal law/ } \\
\text { recommended service }\end{array}$ \\
\hline Induced abortion law & $\begin{array}{l}\text { Only to save the } \\
\text { woman's life }\end{array}$ & $\begin{array}{l}\text { Only to save the } \\
\text { woman's life }\end{array}$ & On request & On request \\
\hline $\begin{array}{l}\text { Ratio of elective to } \\
\text { post-abortion care cases }\end{array}$ & $0 \% / 100 \%$ & $0 \% / 100 \%$ & $50 \% / 50 \%$ & $100 \% / 0 \%$ \\
\hline $\begin{array}{l}\text { Level for provision of } \\
\text { abortion care }\end{array}$ & $\begin{array}{l}\text { Secondary and } \\
\text { tertiary }\end{array}$ & $\begin{array}{l}\text { Primary, secondary } \\
\text { and tertiary }\end{array}$ & Secondary and tertiary & $\begin{array}{l}\text { Primary, secondary } \\
\text { and tertiary }\end{array}$ \\
\hline Abortion care providers & $\begin{array}{l}\text { General practitioner } \\
\text { and obstetrician/ } \\
\text { gynaecologist }\end{array}$ & $\begin{array}{l}\text { Mid-level provider,a } \\
\text { general practitioner, } \\
\text { and obstetrician/ } \\
\text { gynaecologist }\end{array}$ & $\begin{array}{l}\text { General practitioner } \\
\text { and obstetrician/ } \\
\text { gynaecologist }\end{array}$ & $\begin{array}{l}\text { Mid-level provider, a } \\
\text { general practitioner, } \\
\text { and obstetrician/ } \\
\text { gynaecologist }\end{array}$ \\
\hline $\begin{array}{l}\text { Uterine evacuation } \\
\text { method }\end{array}$ & Dilation and curettage & Vacuum aspiration & $\begin{array}{l}\text { Dilation and } \\
\text { curettage }\end{array}$ & Vacuum aspiration \\
\hline $\begin{array}{l}\text { Pain management for } \\
\text { invasive procedures }\end{array}$ & General anaesthesia & Light sedation & General anaesthesia & Light sedation \\
\hline $\begin{array}{l}\text { Reproductive health and } \\
\text { contraception counselling }\end{array}$ & Yes & Yes & Yes & Yes \\
\hline $\begin{array}{l}\text { Contraceptive method } \\
\text { acceptance }\end{array}$ & $14 \%$ of cases & $14 \%$ of cases & $14 \%$ of cases & $14 \%$ of cases \\
\hline
\end{tabular}

aProvider with $\geq 3$ years of graduate-level education.

facility-level costs rather than estimating costs for the broader health system..$^{9,15,19}$

'Savings' users can project the costs of abortion-related care by entering data on cost variables from their geopolitical area of interest. Users can vary the assumptions (e.g. the legal status of abortion, the type of uterine evacuation method, the level the health system at which care is offered or the type of provider who offers care) to compare abortion care costs within a range of policy frameworks and service delivery scenarios. In this article we present cost estimates from applications of the model to four scenarios of common policy and service delivery settings, using published data primarily from Uganda, in order to illustrate the expected differences in cost.

\section{Methodology}

\section{Model description}

In the 'Savings' model service delivery scenarios can differ according to the following seven variables:

- health care system level (i.e. tertiary, secondary or primary) for abortion care provision;

- level of remuneration for providers of abortion care [i.e. gynaecologists, general practitioners (GPs), midwives or other mid-level providers with $\geq 3$ years of graduatelevel training, or midwives or other mid-level providers with $<3$ years of graduate-level training];

- type of facility used (i.e. operating theatre or outpatient);

- uterine evacuation method used (e.g. D\&C or vacuum aspiration);

- pain control method (i.e. general anaesthesia or light sedation);

- counselling provided (e.g. abortion/reproductive health and contraceptive counselling); and

- facility costs for client waiting and recovery times (e.g. meals, linens and cleaning materials).

Treatment costs are calculated as the sum of abortion care services for each health care system level. Costed services include: physical examination, restoration of fluids, administration of antibiotics, uterine evacuation, cervical and vaginal laceration repair, uterine laceration repair and hysterectomy, laboratory tests, counselling, contraceptive supplies, and facility-related costs of client waiting and recovery time. Costs also account for provider time (based on salary, benefits and length of time needed for each procedure), manual vacuum aspiration equipment and other essential medical supplies (e.g. gloves, antibiotics, linens and cleaning materials). The model includes recurrent costs, and not overhead and capital costs such as buildings, large equipment and essential durable equipment including specula, forceps and autoclaves.

\section{Model application}

We defined four archetypical service delivery strategies, each designed to capture the main features of service delivery approaches that currently exist in the developing world (Table 1). Two strategies assume a 'restrictive' abortion law or policy (i.e. abortion permitted only to save a woman's life) and two assume a 'liberal' abortion law or policy (i.e. first-trimester abortion available on request). Within the two types of legal settings we compared a 'recommended' approach to providing abortion services using decentralised services and technically superior interventions (e.g. vacuum aspiration) versus a centralised 'conventional' approach relying on centralised care and more costly interventions (e.g. D\&C performed by specialist physicians).

Our goal was to establish the utility of the model and assess the order of magnitude of the difference in costs of care when different service delivery approaches are used. For this application, we used available data from the Ugandan Safe Motherhood Programme Costing Study implemented by the Ugandan Ministry of Health and the World Health Organization, ${ }^{26}$ supplemented by other sources as needed. We used published data for estimating provider salaries; amount and cost of supplies; ${ }^{23,26,27}$ time required for performing induced abortion 15 or for providing care for unsafe abortion complications; 28 and method mix and contraceptive acceptance rates. ${ }^{29}$ Our 
Johnston et al.

Table 2 Services required by women presenting with complications of unsafe abortiona

\begin{tabular}{|c|c|c|}
\hline Service & $\begin{array}{l}\text { Patients } \\
\text { requiring } \\
\text { service }(\%)\end{array}$ & $\begin{array}{l}\text { Health system } \\
\text { level providing } \\
\text { service }\end{array}$ \\
\hline Examination & $100 \%$ & All \\
\hline $\begin{array}{l}\text { Restoration of fluid } \\
\text { volume }\end{array}$ & $10 \%$ & $\begin{array}{l}\text { Secondary and } \\
\text { tertiary }\end{array}$ \\
\hline $\begin{array}{l}\text { Administration of } \\
\text { antibiotics }\end{array}$ & $100 \%$ & All \\
\hline Uterine evacuation & $75 \%$ & All \\
\hline $\begin{array}{l}\text { Repair of cervical or } \\
\text { vaginal lacerations }\end{array}$ & $5 \%$ & $\begin{array}{l}\text { Secondary and } \\
\text { tertiary }\end{array}$ \\
\hline $\begin{array}{l}\text { Repair of uterine } \\
\text { lacerations or } \\
\text { hysterectomiesc }\end{array}$ & $10 \%$ & Tertiary \\
\hline Laboratory tests & $100 \%$ & All \\
\hline $\begin{array}{l}\text { Reproductive health and } \\
\text { contraceptive counselling }\end{array}$ & $100 \%$ & All \\
\hline
\end{tabular}

aSource: WHO (1999). ${ }^{23}$

bSource: Gebreselassie et al. (2005). ${ }^{30}$

cRequiring laparotomy under general anesthesia.

estimates of waiting and recovery time (stratified by uterine evacuation method) were based on a study conducted in Kenya. ${ }^{19}$ Data from the WHO Mother-Baby Package Costing Spreadsheet ${ }^{23}$ and a Kenya-based study 30 were used to estimate the proportion of complications occurring (Table 2). All cost estimates were normalised to 1996 US dollar trade values. We choose to use 1996 dollars because core data from Uganda refer to 1996 costs. (NB. Full tables of estimates used are available from the corresponding author.)

\section{Assumptions}

We assume that each scenario would treat the same number of cases, although the ratio of elective abortion to emergency post-abortion care cases would differ. All elective abortion procedures are assumed to occur in the first trimester while the complications could be a result of first- or second-trimester abortion. Table 2 lists the estimated proportion of emergency post-abortion cases receiving services and the facility level where the services are provided. ${ }^{23,30}$ While the proportions of complication types are presumed to remain constant across the three health care facility levels, we expect patients to be referred successfully to the appropriate level if a necessary service is not available at a given level. The quality of care is

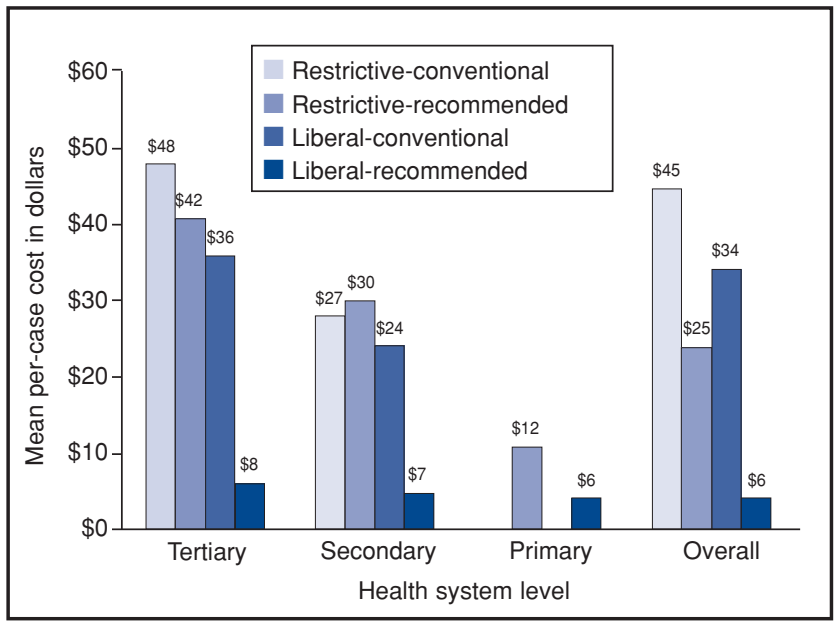

Figure 1 Mean per-case cost of abortion care by health system level and archetype considered to be consistent across the scenarios; for example, all cases receive reproductive health and contraceptive counselling. Furthermore, all care is assumed to be provided in the public sector and in conformity with the law. Finally, the model does not include costs external to the health care system; we do not capture the costs to women and their families of abortion-related morbidity or the impact of lost lives.

\section{Results}

\section{Restricted-conventional scenario}

The restricted-conventional scenario reflects a setting where elective abortion except to save the woman's life is banned, and emergency treatment for the complications of unsafe abortion is not available at the primary care level (Table 3). Cases are managed by GPs at the secondary level $(15 \%)$ and gynaecologists at the tertiary level $(85 \%)$. D\&C with general anaesthesia is used for uterine evacuations. All patients presenting at the secondary level with uterine lacerations $(10 \%)$ are referred to the tertiary level for care. The mean cost of care per patient for the restrictedconventional scenario is $\$ 27$ at the secondary level, $\$ 48$ at the tertiary level and $\$ 45$ overall (Figure 1). The higher cost at the tertiary level is attributable to two procedures, which in this scenario are available only at the tertiary level (i.e. repair of uterine laceration and restoration of fluids) as well as increased provider costs and higher costs associated with longer waiting and recovery times.

\section{Restricted-recommended scenario}

The restricted-recommended scenario reflects a setting that bans elective abortion but has accessible services to treat complications at the three system levels (Table 4). Most patients $(60 \%)$ present at the primary care level where care is managed by mid-level providers (e.g. midwives, clinical officers) with $\geq 3$ years of graduate-level education. The remainder is treated by GPs at the secondary care level $(25 \%)$ and gynaecologists at the tertiary care level (15\%). Vacuum aspiration with light sedation is used for uterine evacuation at the three system levels. Five percent of the patients presenting to the primary care level require care for cervical laceration: half of these are assumed to also have uterine lacerations and are included in the $10 \%$ who are referred directly to the tertiary level for care. The mean cost per case for this scenario is $\$ 12, \$ 30$ and $\$ 42$ for the primary, secondary and tertiary levels, respectively, and \$25 overall. Uterine laceration repair and fluid restoration (available only at secondary and tertiary levels) are responsible for the increased costs at the upper levels. The decrease in mean costs compared to those in the restrictedconventional scenario is due mainly to the use of vacuum aspiration with light sedation instead of D\&C with general anaesthesia. These changes also allow for the use of midlevel providers and shorter waiting and recovery times.

\section{Liberal-conventional scenario}

Although the third scenario, liberal-conventional, allows for elective abortion, services are difficult to access as the primary facility level does not provide abortion-related care (Table 5). Thus, half of the cases are for elective abortion and half are for complications from unsafe abortion. Most cases $(82 \%)$ are managed by gynaecologists at the tertiary level while the remainder is treated by GPs at the secondary level. Uterine evacuation in all cases is performed with D\&C using general anaesthesia. Again, the $10 \%$ of patients presenting to the secondary care level with uterine laceration are referred to the tertiary care level. The mean cost per elective abortion case is $\$ 21$ at the secondary and $\$ 23$ at the tertiary level, while the mean cost per case 
Table 3 Per-case costs of care in US dollars by service and health system level: Restricted-conventional scenario

\begin{tabular}{|c|c|c|c|c|c|c|c|c|}
\hline \multirow[t]{2}{*}{ Service } & \multicolumn{2}{|c|}{ Primary care level } & \multicolumn{2}{|c|}{ Secondary care level } & \multicolumn{2}{|c|}{ Tertiary care level } & \multicolumn{2}{|l|}{ All levels } \\
\hline & $\begin{array}{l}\text { Patients } \\
(\%)\end{array}$ & $\begin{array}{l}\text { Cost per } \\
\text { patient } \\
\text { (\$) }\end{array}$ & $\begin{array}{l}\text { Patients } \\
(\%)\end{array}$ & $\begin{array}{l}\text { Cost per } \\
\text { patient } \\
(\$)\end{array}$ & $\begin{array}{l}\text { Patients } \\
(\%)\end{array}$ & $\begin{array}{l}\text { Cost per } \\
\text { patient } \\
(\$)\end{array}$ & $\begin{array}{l}\text { Patients } \\
\text { (\%) }\end{array}$ & $\begin{array}{l}\text { Cost per } \\
\text { patient } \\
(\$)\end{array}$ \\
\hline \multicolumn{9}{|l|}{ Post-abortion care } \\
\hline Waiting time (costs to facility) a & - & - & 15.0 & 3.19 & 86.5 & 7.97 & $101.5^{\mathrm{e}}$ & 7.26 \\
\hline Examinationa & - & - & 15.0 & 1.32 & 86.5 & 1.68 & $101.5 \mathrm{e}$ & 1.62 \\
\hline Restoration of fluid volumeb & - & - & - & - & 10.0 & 75.25 & 10.0 & 75.25 \\
\hline Administration of antibiotics & - & - & 13.5 & 6.45 & 86.5 & 6.62 & 100.0 & 6.60 \\
\hline Uterine evacuation & - & - & 9.7 & 16.95 & 65.3 & 18.47 & 75.0 & 18.27 \\
\hline Repair of cervical or vaginal lacerations ${ }^{c}$ & - & - & 0.4 & 4.77 & 4.6 & 7.07 & 0.05 & 6.90 \\
\hline $\begin{array}{l}\text { Repair of uterine lacerations or } \\
\text { hysterectomies }^{d}\end{array}$ & - & - & - & - & 10.0 & 27.29 & 10.0 & 27.29 \\
\hline Laboratory tests & - & - & 13.5 & 0.75 & 86.5 & 0.75 & 100.0 & 0.75 \\
\hline $\begin{array}{l}\text { Reproductive health and contraceptive } \\
\text { counselling }\end{array}$ & - & - & 13.5 & 0.75 & 86.5 & 0.75 & 100.0 & 0.75 \\
\hline $\begin{array}{l}\text { Post-abortion contraception (commodity } \\
\text { costs only) }\end{array}$ & - & - & 13.5 & 0.13 & 86.5 & 0.13 & 100.0 & 0.13 \\
\hline $\begin{array}{l}\text { Recovery (costs to facility) } \\
\text { Average cost per case }\end{array}$ & - & - & 13.5 & $\begin{array}{r}1.39 \\
26.84\end{array}$ & 86.5 & $\begin{array}{r}3.63 \\
47.68\end{array}$ & 100.0 & $\begin{array}{r}3.33 \\
44.87\end{array}$ \\
\hline
\end{tabular}

alf patients require higher level care they are referred after an examination and receive their care at the higher level. Thus, the total number of waiting experiences and examinations exceeds the total number of patients.

bThe $10 \%$ of patients requiring restoration of fluid volume are assumed to have other complications and would have been referred to tertiary care.

c10\% of all cervical laceration patients are assumed to also have uterine lacerations and would have been referred to tertiary care.

dRequiring laparotomy, general anaesthesia. Patients requiring repair of uterine lacerations and hysterectomies would have been referred to tertiary care level.

eTotal exceeds 100 due to rounding error.

involving abortion complications is $\$ 27$ at the secondary and $\$ 48$ at the tertiary level, due to the more costly services required. The overall mean cost per case is $\$ 34$. The cost differences between the secondary and tertiary levels result from the types of care offered at each level as well as the use at the tertiary level of general anaesthesia and more highly trained (and more costly) staff.

\section{Liberal-recommended scenario}

Finally, the liberal-recommended scenario reflects a setting where elective abortion is legally permitted, with care accessible at all three system levels (Table 6). As an example of model inputs, Table 7 shows the recurrent component costs included at the primary care level in this scenario. Most abortion care $(85 \%)$ is provided at the primary care level by mid-level providers with $\geq 3$ years of graduate-level education while the remainder is provided by GPs at the secondary level $(10 \% ; 2 \%$ assumed to be complicated cases) and gynaecologists at the tertiary care level (5\%; all assumed to be complicated cases). The three facility levels use vacuum aspiration with light sedation for uterine evacuation. The mean costs per case at the primary, secondary and tertiary levels are $\$ 6, \$ 7$ and $\$ 8$, respectively, and $\$ 6$ overall. A substantial part of these

Table 4 Per-case costs of care in US dollars by service and health system level: Restricted-recommended scenario

\begin{tabular}{|c|c|c|c|c|c|c|c|c|}
\hline \multirow[t]{2}{*}{ Service } & \multicolumn{2}{|c|}{ Primary care level } & \multicolumn{2}{|c|}{ Secondary care level } & \multicolumn{2}{|c|}{ Tertiary care level } & \multicolumn{2}{|l|}{ All levels } \\
\hline & $\begin{array}{l}\text { Patients } \\
(\%)\end{array}$ & $\begin{array}{l}\text { Cost per } \\
\text { patient } \\
\text { (\$) }\end{array}$ & $\begin{array}{l}\text { Patients } \\
(\%)\end{array}$ & $\begin{array}{l}\text { Cost per } \\
\text { patient } \\
\text { (\$) }\end{array}$ & $\begin{array}{l}\text { Patients } \\
(\%)\end{array}$ & $\begin{array}{l}\text { Cost per } \\
\text { patient } \\
(\$)\end{array}$ & $\begin{array}{l}\text { Patients } \\
(\%)\end{array}$ & $\begin{array}{l}\text { Cost per } \\
\text { patient } \\
(\$)\end{array}$ \\
\hline \multicolumn{9}{|l|}{ Post abortion care } \\
\hline Waiting time (costs to facility)a & 60.0 & 1.45 & 26.5 & 1.45 & 23.5 & 3.63 & 132.5 & 1.91 \\
\hline Examinationa ${ }^{a}$ & 60.0 & 0.72 & 26 & 0.72 & 23.5 & 0.72 & 132.5 & 0.72 \\
\hline Restoration of fluid volumeb & - & - & 6.0 & 74.97 & 4.0 & 74.97 & 10.0 & 74.97 \\
\hline Administration of antibiotics & 51.0 & 6.34 & 25.5 & 6.34 & 23.5 & 6.34 & 100.0 & 6.34 \\
\hline Uterine evacuation & 38.3 & 2.91 & 19.1 & 2.91 & 17.6 & 2.91 & 75.0 & 2.91 \\
\hline Repair of cervical or vaginal lacerations ${ }^{c}$ & - & - & 2.1 & 4.77 & 2.8 & 5.83 & 50.0 & 5.38 \\
\hline $\begin{array}{l}\text { Repair of uterine lacerations or } \\
\text { hysterectomies }\end{array}$ & - & - & - & - & 10.0 & 27.29 & 10.0 & 27.29 \\
\hline Laboratory tests & 51.0 & 0.75 & 25.5 & 0.75 & 23.5 & 0.75 & 100.0 & 0.75 \\
\hline $\begin{array}{l}\text { Reproductive health and contraceptive } \\
\text { counselling }\end{array}$ & 51.0 & 0.75 & 25.5 & 0.75 & 23.5 & 0.75 & 100.0 & 0.75 \\
\hline $\begin{array}{l}\text { Postabortion contraception (commodity } \\
\text { costs only) }\end{array}$ & 51.0 & 0.13 & 25.5 & 0.13 & 23.5 & 0.13 & 100.0 & 0.13 \\
\hline $\begin{array}{l}\text { Recovery (costs to facility) } \\
\text { Average cost per case }\end{array}$ & 51.0 & $\begin{array}{r}0.85 \\
11.51\end{array}$ & 25.5 & $\begin{array}{r}0.85 \\
30.24\end{array}$ & 23.5 & $\begin{array}{r}2.13 \\
41.70\end{array}$ & 100.0 & $\begin{array}{r}1.15 \\
24.72\end{array}$ \\
\hline
\end{tabular}

alf patients require higher level care they are referred after an examination and receive their care at the higher level. Thus, the total number of waiting experiences and examinations exceeds the total number of patients. In this scenario, $50 \%$ of primary care patients are referred from primary to secondary level, and $10 \%$ of patients are referred from primary to tertiary and secondary to tertiary.

bThe $10 \%$ of patients requiring restoration of fluid volume are assumed to have other complications and would have been referred to tertiary care.

cAll patients presenting to the primary care level with cervical laceration would have been referred to the secondary care level.

dRequiring laparotomy, general anaesthesia. Patients requiring repair of uterine lacerations and hysterectomies would have been referred to tertiary care level. 
Johnston et al.

Table 5 Per-case costs of care in US dollars by service and health system level: Liberal-conventional scenario

\begin{tabular}{|c|c|c|c|c|c|c|c|c|}
\hline \multirow[t]{2}{*}{ Service } & \multicolumn{2}{|c|}{ Primary care level } & \multicolumn{2}{|c|}{ Secondary care level } & \multicolumn{2}{|c|}{ Tertiary care level } & \multicolumn{2}{|l|}{ All levels } \\
\hline & $\begin{array}{l}\text { Patients } \\
\text { (\%) }\end{array}$ & $\begin{array}{l}\text { Cost per } \\
\text { patient } \\
\text { (\$) }\end{array}$ & $\begin{array}{l}\text { Patients } \\
(\%)\end{array}$ & $\begin{array}{l}\text { Cost per } \\
\text { patient } \\
\text { (\$) }\end{array}$ & $\begin{array}{l}\text { Patients } \\
(\%)\end{array}$ & $\begin{array}{l}\text { Cost per } \\
\text { patient } \\
(\$)\end{array}$ & $\begin{array}{l}\text { Patients } \\
(\%)\end{array}$ & $\begin{array}{l}\text { Cost per } \\
\text { patient } \\
\text { (\$) }\end{array}$ \\
\hline \multicolumn{9}{|l|}{ Elective abortion } \\
\hline Examination & - & - & 10.0 & 0.96 & 40.0 & 1.32 & 50.0 & 1.25 \\
\hline Pre-abortion counselling & - & - & 10.0 & 0.41 & 40.0 & 0.41 & 50.0 & 0.41 \\
\hline Laboratory tests & - & - & 10.0 & 1.41 & 40.0 & 1.41 & 50.0 & 1.41 \\
\hline Uterine evacuation & - & - & 10.0 & 17.17 & 40.0 & 18.69 & 50.0 & 18.39 \\
\hline Recovery (costs to facility) & - & - & 10.0 & 0.25 & 40.0 & 0.63 & 50.0 & 0.55 \\
\hline Reproductive health and contraceptive & & & & & & & & \\
\hline $\begin{array}{l}\text { counselling } \\
\text { Post-abortion contraception (commodity }\end{array}$ & - & - & 10.0 & 0.60 & 40.0 & 0.60 & 50.0 & 0.60 \\
\hline $\begin{array}{l}\text { Post-abortion contraception (commodity } \\
\text { costs only) } \\
\text { Average cost per elective abortion client }\end{array}$ & - & - & 10.0 & $\begin{array}{r}0.13 \\
20.93\end{array}$ & 40.0 & $\begin{array}{r}0.13 \\
23.18\end{array}$ & 50.0 & $\begin{array}{r}0.13 \\
22.73\end{array}$ \\
\hline \multicolumn{9}{|l|}{ Post-abortion care } \\
\hline Waiting time (costs to facility) a & - & - & 10.0 & 3.19 & 41.0 & 7.97 & 51.0 & 7.03 \\
\hline Examinationa & - & - & 10.0 & 1.32 & 41.0 & 1.68 & 51.0 & 1.61 \\
\hline Restoration of fluid volumeb & - & - & - & - & 5.0 & 75.25 & 5.0 & 75.25 \\
\hline Administration of antibiotics & - & - & 9.0 & 6.45 & 41.0 & 6.62 & 50.0 & 6.59 \\
\hline Uterine evacuation & - & - & 6.5 & 16.95 & 31.0 & 18.47 & 37.5 & 18.21 \\
\hline Repair of cervical or vaginal lacerations $c$ & - & - & 0.3 & 4.77 & 2.3 & 7.07 & 2.5 & 6.84 \\
\hline $\begin{array}{l}\text { nysterectomies } \\
\text { Laboratory tests }\end{array}$ & - & - & $9 \overline{0}$ & $0 . \overline{5}$ & 4.0 & $\begin{array}{r}27.29 \\
0.75\end{array}$ & 5.0 & $\begin{array}{r}27.29 \\
0.75\end{array}$ \\
\hline Reproductive health and contraceptive & & & & & & & & \\
\hline counselling & - & - & 9.0 & 0.75 & 41.0 & 0.75 & 50.0 & 0.75 \\
\hline $\begin{array}{l}\text { Post-abortion contraception (commodity } \\
\text { costs only) }\end{array}$ & & & & & & & & \\
\hline $\begin{array}{l}\text { costs only) } \\
\text { Recovery (costs to facility) }\end{array}$ & 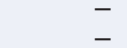 & - & $\begin{array}{l}9.0 \\
9.0\end{array}$ & $\begin{array}{l}0.13 \\
139\end{array}$ & $\begin{array}{l}41.0 \\
41.0\end{array}$ & $\begin{array}{l}0.13 \\
3.64\end{array}$ & $\begin{array}{l}50.0 \\
50.0\end{array}$ & $\begin{array}{l}0.13 \\
3.23\end{array}$ \\
\hline Average cost per post-abortion care patient & & - & & 26.84 & & 48.39 & & 44.51 \\
\hline Average cost per case & & _- & & 23.73 & & 35.93 & & 33.61 \\
\hline
\end{tabular}

alf patients require higher level care they are referred after an examination and receive their care at the higher level. Thus, the total number of waiting experiences and examinations exceeds the total number of patients.

bThe $10 \%$ of patients requiring restoration of fluid volume are assumed to have other complications and would have been referred to tertiary care.

c50\% of all cervical laceration patients are assumed to also have uterine lacerations and would have been referred to tertiary care.

dRequiring laparotomy, general anaesthesia. Patients requiring repair of uterine lacerations and hysterectomies would have been referred to tertiary care level.

costs is attributable to the provider time required to perform the uterine evacuation, estimated at $\$ 1$ on average, while the difference in costs between levels is related to the cadre of clinician providing care.

\section{Discussion}

Applying data from Uganda to alternative service delivery scenarios in the model demonstrates that using recommended technical interventions for abortion-related care within a decentralised system yields substantial savings to the health care system in comparison to using a conventional, centralised approach regardless of the legal status of elective abortion. Changing from the restrictedconventional setting to the restricted-recommended setting decreases the mean cost per unsafe abortion complication case by $43 \%$ (i.e. from $\$ 45$ to $\$ 25$ ). Similarly, the use of the liberal-recommended scenario instead of the liberalconventional scenario reduces costs by $81 \%$ (i.e. from $\$ 34$ to $\$ 6)$.

Changing from a restrictive to liberal elective abortion law also decreases costs. The use of a liberal-conventional scenario instead of its restrictive-conventional counterpart reduces abortion-related service costs by $24 \%$ (i.e. from $\$ 45$ to $\$ 34)$. While this constitutes a substantial saving, the

Table 6 Per-case costs of care in US dollars by service and health system level: Liberal-recommended scenario

\begin{tabular}{|c|c|c|c|c|c|c|c|c|}
\hline \multirow[t]{2}{*}{ Service } & \multicolumn{2}{|c|}{ Primary care level } & \multicolumn{2}{|c|}{ Secondary care level } & \multicolumn{2}{|c|}{ Tertiary care level } & \multicolumn{2}{|l|}{ All levels } \\
\hline & $\begin{array}{l}\text { Patients } \\
(\%)\end{array}$ & $\begin{array}{l}\text { Cost per } \\
\text { patient } \\
(\$)\end{array}$ & $\begin{array}{l}\text { Patients } \\
(\%)\end{array}$ & $\begin{array}{l}\text { Cost per } \\
\text { patient } \\
(\$)\end{array}$ & $\begin{array}{l}\text { Patients } \\
(\%)\end{array}$ & $\begin{array}{l}\text { Cost per } \\
\text { patient } \\
(\$)\end{array}$ & $\begin{array}{l}\text { Patients } \\
(\%)\end{array}$ & $\begin{array}{l}\text { Cost per } \\
\text { patient } \\
(\$)\end{array}$ \\
\hline \multicolumn{9}{|l|}{ Elective abortion } \\
\hline Examination & 85.0 & 0.72 & 10.0 & 0.84 & 5.0 & 1.32 & 100.0 & 0.76 \\
\hline Pre-abortion counselling & 85.0 & 0.41 & 10.0 & 0.41 & 5.0 & 0.41 & 100.0 & 0.41 \\
\hline Laboratory tests & 85.0 & 1.41 & 10.0 & 1.41 & 5.0 & 1.41 & 100.0 & 1.41 \\
\hline Uterine evacuation & 85.0 & 2.87 & 10.0 & 3.34 & 5.0 & 4.04 & 100.0 & 2.97 \\
\hline Recovery (costs to facility) & 85.0 & 0.13 & 10.0 & 0.13 & 5.0 & 0.31 & 100.0 & 0.13 \\
\hline $\begin{array}{l}\text { Reproductive health and contraceptive } \\
\text { counselling } \\
\text { Post-abortion contraception (commodity }\end{array}$ & 85.0 & 0.60 & 10.0 & 0.60 & 5.0 & 0.60 & 100.0 & 0.60 \\
\hline $\begin{array}{l}\text { costs only) } \\
\text { Average cost per elective abortion client }\end{array}$ & 85.0 & $\begin{array}{l}0.13 \\
6.25\end{array}$ & 10.0 & $\begin{array}{l}0.13 \\
6.84\end{array}$ & 5.0 & $\begin{array}{l}0.13 \\
8.21\end{array}$ & 100.0 & $\begin{array}{l}0.13 \\
6.41\end{array}$ \\
\hline
\end{tabular}


Table 7 Recurrent component costs of uterine evacuation at primary care level, liberal-recommended scenario

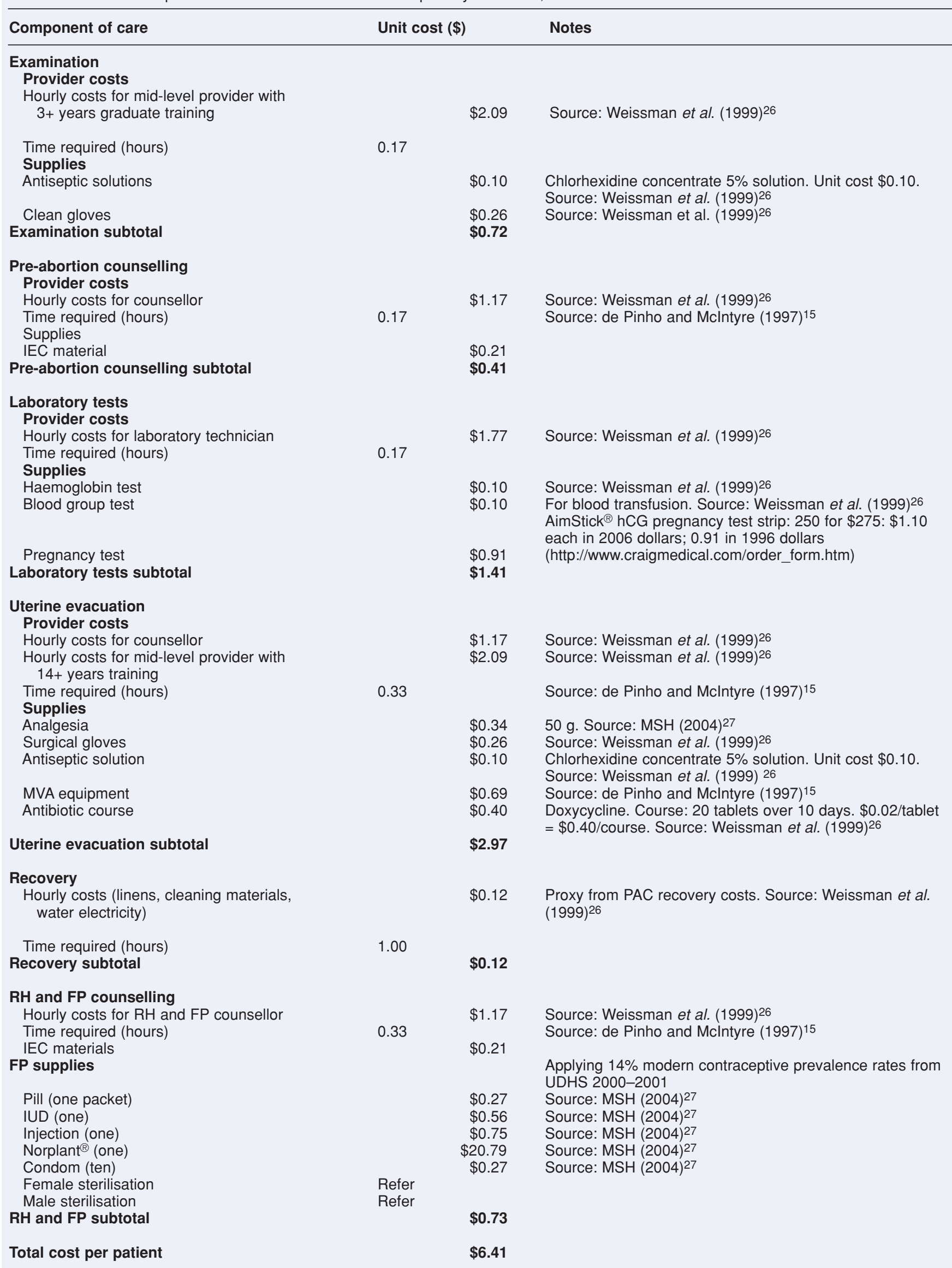

FP, family planning; hCG, human chorionic gonadotropin; IEC, Information, Education and Communication; IUD, intrauterine device; MSH, Management Sciences for Health; MVA, manual vacuum aspiration; PAC, post-abortive care; RH, reproductive health; UDHS, Uganda Demographic and Health Survey. 
rewards are not as great as when the care is strategically planned around recommended interventions at a decentralised level (i.e. restrictive-recommended and liberal-recommended scenarios). Liberalising the abortion law in such a setting reduces the costs by $75 \%$ (i.e. from $\$ 25$ to $\$ 6$ ). The greatest reduction in costs, however, is associated with changing from the conventional system within a restrictive law setting (restrictive-conventional) to a planned, decentralised system within a setting that allows legal, elective abortion (liberal-recommended). This change decreases the mean case cost from $\$ 45$ to $\$ 6$, representing a savings of $86 \%$.

The costs estimated from these applications are similar to those reported from research in other African settings. ${ }^{31}$ For example, the per-case costs of manual vacuum aspiration and $\mathrm{D} \& \mathrm{C}$ for post-abortion care were estimated at \$2-\$6 and \$5-\$17, respectively in Kenya and Tanzania in the 1990s. Estimates for uterine evacuation presented in Tables 3-6 are \$3 for vacuum aspiration and \$18 for D\&C. However, the per-case cost for treatment for septic complications due to illegal abortion was higher, estimated at \$298, in Nigeria in 1987.

This application of the model suggests that contraceptive-related services contribute minimally to the costs of care. Based on the modern contraceptive prevalence of use and method mix reported in 2000-2001 in Uganda, ${ }^{29}$ the per-case contraceptive supply costs for at least 1 month (depending on method type) in each of the four scenarios is estimated at $\$ 0.13$. Even if contraceptive method acceptance were to increase to $100 \%$ (and the proportional method mix remained constant), contraceptives would cost $<\$ 1$ per case. Post-abortion contraceptive counselling and method provision have been shown to yield significant increases in contraceptive acceptance and use, and improved contraceptive services have been shown to reduce unwanted pregnancy. $8,32,33$ Overall, expanding contraceptive services as well as offering elective abortion care in a decentralised setting using recommended techniques appears to be the most cost-effective combination of interventions for health systems. These two approaches also offer the greatest potential for decreasing abortion-related mortality and morbidity.

Besides financial savings, implementing the recommended approach in the restrictive-recommended and the liberal-recommended scenarios should improve the quality of services since vacuum aspiration, a WHOrecommended method of uterine evacuation, is safer than D\&C. ${ }^{3}$ Decentralised abortion care services taking advantage of the skills of mid-level providers are safe,, 34 easier for women to access and require less travel time and expense for women and their families.

Although the model calculates the estimated savings as dollars, the saved resources (e.g. staff time, equipment and supplies) are unlikely to be realised as a reduction in health care costs. Instead, these savings likely would be shifted to other patient services. Another limitation of the model is that differences in mean costs per-case do not always translate proportionately into differences in total costs. For example, the financial gains realised by the public health system from liberalising the abortion law may be reduced if induced abortion cases shift from the private to public health sector. The model also does not account for economies of scale; the marginal cost is treated as if it were the same for every input. Consequently, costs at the primary care level could be underestimated while costs at the tertiary care level are overestimated. Furthermore, start-up costs, administrative costs, capital costs (e.g. electric vacuum aspirator) and some programme costs (e.g. training of providers), which could affect the relative costs of care provision at the three health facility levels, are not included. Also, the recurrent health system costs included in the model might not be comprehensive. For example, we did not include transport costs associated with referral, which, if covered by the health system, would be higher for the scenarios relying on centralised care.

Although the total number of patients presenting to the public health system with complications of unsafe abortion would vary in each scenario, we used consistent rates for specific unsafe abortion complications in the four scenarios. The liberal-recommended scenario assumes that all cases are first-trimester elective abortion, which is unlikely to be the case. Also, this application of the model did not account for any complications from safe elective abortion. A very small percentage of elective abortions would require repeat evacuation; however, including costs of this additional procedure is unlikely to affect the overall conclusions. The four scenarios did not include the costs of medication abortion, since this relatively new technology currently is used in few developing country public health systems and data are scarce regarding its cost in these settings. Finally, the model does not incorporate the social costs (e.g. chronic morbidity or death) to women or their families, although with additional data and assumptions, these could be included in a later-stage version.

In summary, the 'Savings' model suggests that regardless of whether abortion law is restrictive or liberal, a recommended approach based on recommended technical interventions for abortion-related care delivered at a decentralised level could substantially reduce costs compared to a conventional approach. The greatest cost reduction, however, was due to the shift from a conventional approach within a restricted legal setting to a recommended approach within a liberal setting. Given that the spending by the government of Uganda on health averaged $\$ 8$ per person in 2001,35 these reductions represent an important source of savings. Developing country health systems face critical challenges in identifying sufficient resources to meet high demands for services. A shift to a less costly, preferred approach for abortion care would ease some of the burden on stressed health systems, as well as improve abortion service quality and access for women. Furthermore, financial considerations are seldom a major focus in abortion reform movements emphasising principles of public health, human rights and social justice. ${ }^{36}$ By applying data from their own countries to the 'Savings' model, policymakers could gain an additional compelling argument to review laws and introduce recommended approaches to abortion and postabortion care services.

\section{Acknowledgements}

The authors would like to thank Barbara Crane for special comments as well as Deborah Billings, Martha Campbell, Laura Castleman, Ken Hill, Barbara Janowitz, Priya Nanda, Roger Rochat and Ina Warriner for their review of preliminary manuscript drafts. Any errors are the fault of the authors alone. The Department for International Development (DFID) and the World Bank provided financial support for this research; however, the views expressed in this article do not necessarily reflect those of the funding agencies.

\section{Statements on funding and competing interests}

Funding None identified.

Competing interests At the time the study was conducted, Dr Johnston was employed at Ipas. Ipas is a global, non-profit reproductive health organisation focused on safe abortion and women's reproductive rights. Ipas manufactures and distributes manual vacuum aspiration instruments worldwide. 
References

1 United Nations (UN). United Nations Millennium Declaration: Resolution Adopted by the General Assembly. 55/2. New York, NY: UN, 2000

2 World Health Organization (WHO). The Prevention and Management of Unsafe Abortion. Report of a Technical Working Group. Geneva, Switzerland: WHO, 1992.

3 World Health Organization (WHO). Safe Abortion: Technical and Policy Guidance for Health Care Systems. Geneva, Switzerland: WHO, 2003

4 World Health Organization (WHO). Unsafe Abortion: Global and Regional Estimates of the Incidence of Unsafe Abortion and Associated Mortality in 2000. Geneva, Switzerland: WHO, 2004.

5 Alan Guttmacher Institute. Sharing Responsibility: Women, Society and Abortion Worldwide. New York, NY: The Alan Guttmacher Institute, 1999.

6 United Nations (UN). Programme of Action Adopted at the International Conference on Population and Development, Cairo 5-13 September 1994. New York, NY: UN, 1994.

7 Salter CL, Johnston HB, Hengen N. Care for postabortion complications: saving women's lives. Popul Rep L 1997; 10: 1.

8 Billings DL, Benson J. Postabortion care in Latin America: policy and service recommendations from a decade of operations research. Health Policy Plan 2005; 20: 158-166.

9 Koontz SL, Molina de Perez O, Leon K, Foster-Rosales A. Treating incomplete abortion in El Salvador: cost savings with manual vacuum aspiration. Contraception 2003; 68: 345-351.

10 Dickson-Tetteh K, Billings DL. Abortion care services provided by registered midwives in South Africa. Int Fam Plan Perspect 2002; 28: 144-150.

11 Ipas, Division of International Health (IHCAR). Deciding Women's Lives are Worth Saving: Expanding the Role of Midlevel Providers in Safe Abortion Care. Chapel Hill, NC: Ipas, 2002.

12 Dayaratna V, Winfrey W, McGreevy W, Hardee K, Smith J, Mumford E, et al. Reproductive Health Interventions: Which Ones Work and What Do They Cost? Washington, DC: The Futures Group International, 2000.

13 Jowett $M$. Safe motherhood interventions in low-income countries: an economic justification and evidence of cost effectiveness. Health Policy 2000; 53: 201-228.

14 Huntington D, Nawar L, Hassan EO, Youssef H, Abdel-Tawab $\mathrm{N}$. The postabortion caseload in Egyptian hospitals: a descriptive study. Int Fam Plan Perspect 1998; 24: 25-31.

15 de Pinho H, Mclntyre D. Cost Analysis of Abortions Performed in the Public Sector. Cape Town, South Africa: University of Cape Town Department of Health, 1997.

16 King T, Benson J, Stein K. Comparing the Cost of Postabortion Care in Africa and Latin America: The DataPAC Project. New York, NY: Population Council, 1997.

17 Blumenthal PD, Remsburg RE. A time and cost analysis of the management of incomplete abortion with manual vacuum aspiration. Int J Gynaecol Obstet 1994; 45: 261-267.

18 Bradley J, Rogo K, Johnson R, Okoko L, Healy J, Benson J. A comparison of the costs of manual vacuum aspiration (MVA) and evacuation and curettage (E and $C)$ in the treatment of early incomplete abortions in Kenya. J Obstet Gynaecol East Cent Africa 1993; 11: 12-19.

19 Johnson BR, Benson J, Bradley J, Ordoñez AR. Costs and resource utilization for the treatment of incomplete abortion in Kenya and Mexico. Soc Sci Med 1993; 36: 1443-1453.

20 Management Sciences for Health (MSH). CORE: A Tool for Cost and Revenue Analysis, User's Guide: Version 1.0. Boston, MA: MSH, 1998.

21 Management Sciences for Health (MSH), John Snow, Inc., United States Pharmacopeia. CES: Cost-Estimate Strategy for Reproductive Health Commodity Management, User's Guide. Arlington, VA: MSH, 2000

22 The Policy II Project. Washington, DC: Policy Project, 2007. http://www.policyproject.com/software.cfm?page=Software\& ID=Spectrum [Accessed 10 April 2007].

23 World Health Organization (WHO). Mother-Baby Package Costing Spreadsheet. Geneva, Switzerland: WHO Reproductive Health and Research Unit, 1999.

24 Janowitz B, Bratt JH. Methods for Costing Family Planning Services. New York, NY: United Nations Populations Fund and Family Health International, 1999.

25 PRIME II. Cost and Results Analysis: Practical Applications in International Health from the PRIME II Project. Better Practices in Performance Improvement. Chapel Hill, NC: PRIME II, 2003.

26 Weissman E, Sentumbwe-Mugisa O, Mbonye AK, Kayaga E Kihuguru SM, Lissner C. Uganda Safe Motherhood Programme Costing Study. Geneva, Switzerland: World Health Organization, 1999.

27 Management Sciences for Health (MSH). The International Drug Price Indicator Guide, 2003. Boston, MA: MSH, 2004.

28 Nawar L, Huntington D, Fattah MNA. Cost analysis of postabortion care in Egypt. In: Huntington D, Piet-Pelon NJ (eds), Postabortion Care: Lessons Learned from Operations Research. New York, NY: Population Council, 1999.

29 Uganda Bureau of Statistics (UBOS), ORC Macro. Uganda Demographic and Health Survey 2000-2001. Calverton, MD: UBOS and ORC Macro, 2001

30 Gebreselassie H, Gallo MF, Monyo A, Johnson BR. The magnitude of abortion complications in Kenya. $\mathrm{Br} \mathrm{J}$ Obstet Gynaecol 2005; 112: 1229-1235.

31 Mumford EA, Dayaratna V, Winfrey W, Since J, McGreevey WP. Reproductive Health Costs: Literature Review. Policy Project, Working Paper Series No. 3, 1998. http://www.policyproject.com/abstract.cfm/240 [Accessed 13 March 2006].

32 Johnson BR, Ndhlovu S, Farr SL, Chipato T. Reducing unplanned pregnancy and abortion in Zimbabwe through postabortion contraception. Stud Fam Plann 2002; 33: 195-202.

33 Solo J, Billings DL, Aloo-Obunga C, Ominde A, Makumi M. Creating linkages between incomplete abortion treatment and family planning services in Kenya. Stud Fam Plann 1999; 30: 17-27.

34 Warriner IK, Meiric O, Hoffman M, Morroni C, Harries J, My Huong NT, et al. Rates of complication in first trimester manual vacuum aspiration abortion done by doctors and mid-level providers in South African and Vietnam: a randomized controlled equivalence trial. Lancet 2006; 368: 1965-1972.

35 World Health Organization (WHO). World Health Report 2004: Changing History. Geneva, Switzerland: WHO, 2004.

36 Cook RJ, Dickens BM, Fathalla MF. Reproductive Health and Human Rights: Integrating Medicine, Ethics, and Law. New York, NY: Oxford University Press, 2003.

NEWS ROUNDUP

\section{Celebrating 20 years of Positively \\ Women}

The HIV charity, Positively Women, has launched a special edition of its magazine to mark the organisation's 20th anniversary. The commemorative edition features the stories of 24 women diagnosed over the last 20 years. The different stories illustrate the changing attitudes and treatment of women living with HIV over the last two decades.

For further information contact Lucy Osman on 02077130444 or email losman@positively women.org.uk.

\section{Independent Advisory Group on Sexual Health and HIV}

Strong links between alcohol, drugs and risky sexual behaviour are providing fuel for a "sexual health crisis" in Britain. Sexual health among the young has deteriorated seriously in the last 12 years, and media coverage of celebrities' hardpartying lifestyles may make the problem worse, are key findings of the Independent Advisory Group on Sexual Health. "Young people, from their early teens, are defining a lifestyle that involves alcohol, drugs and sex", said the group's Chair, Baroness Joyce Gould.

The report found that Britain had the highest rate of sexually transmitted infections (STIs) and teenage pregnancy in Europe. There has been a "disturbing" increase in STIs - over the last 12 years, chlamydia and HIV are up $300 \%$ and syphilis $2000 \%$. The study found a "strong correlation" between STIs, sex and drug use and added that alcohol "can increase the risk of having unprotected sex". The report also highlighted the impact that advertising and celebrities can have from a young age, citing the "publicity and coverage of sex, drugs and excessive drinking by 'celebrities' and 'pop dols' and by characters in 'soaps', making it an acceptable lifestyle". The report's authors "ecommended a more collaborative and less "puritanical" official approach to the issues and said condoms should be more accessible to young people and sex education mandatory in schools. Factors including young people having parents who were ambitious for them plus a confidante as well as achievement at school were all helpful.

Source: http://www.dh.gov.uk/en/Policyandguidance/Healthand socialcaretopics/Sexualhealth/Sexualhealthgeneralinfor mation/DH_4079794

Reported by Henrietta Hughes, MRCGP, DFFP General Practitioner, London, UK 